\title{
Increasing incidence of Kaposi's sarcoma in black South Africans In Kwazulu-Natal, South Africa (1983 to 2006)
} TS Uldrick*1,2, A Mosam³, H Carrara ${ }^{3}$, F Shaik ${ }^{2,3}$, A Berkman ${ }^{1,2}$ and HM Coovadia ${ }^{4}$

Address: ${ }^{1}$ Mailman School of Public Health, Columbia University, New York, USA, ${ }^{2}$ South Africa Fogarty AIDS International Training and Research Program, Columbia University, New York, USA, ${ }^{3}$ Department of Dermatology, Nelson R. Mandela School of Medicine, University of KwaZuluNatal, South Africa and ${ }^{4}$ Victor Daitz Chair of HIV Research, Doris Duke Medical Research Institute, Nelson R. Mandela School of Medicine, University of KwaZulu-Natal, South Africa

* Corresponding author

from I I th International Conference on Malignancies in AIDS and Other Acquired Immunodeficiencies (ICMAOI): Basic, Epidemiologic, and Clinical Research

Bethesda, MD, USA. 6-7 October 2008

Published: 17 June 2009

Infectious Agents and Cancer 2009, 4(Suppl 2):P42 doi:10.1186/1750-9378-4-S2-P42

This abstract is available from: http://www.infectagentscancer.com/content/4/S2/P42

(C) 2009 Uldrick et al; licensee BioMed Central Ltd.

\section{Objective}

AIDS-associated Kaposi's sarcoma (KS) is a common malignancy in regions with high HIV and Kaposi's Sarcoma-Associated Virus (KSHV) co-infection. This is exacerbated by limited access to antiretroviral therapy. Despite the dramatic increase in HIV in South Africa since the mid-1990s, little is known about the rates of AIDS-associated KS. Our objective is to estimate trends in the incidence of AIDS-associated KS in black South Africans in KwaZulu-Natal.

\section{Design}

Observational database analysis.

\section{Methods}

The incidence of KS (per 100,000) was estimated using anonymous administrative records for patients receiving care for KS through all public sector oncology clinics in KwaZulu-Natal, 1983 to 2006. Age-standardized incidence rates were calculated annually using provincial census data for the black population from 1985, 1996, 2001 and 2005. Age-specific rates were calculated for 19831989 (baseline) and for 2006 (generalized HIV epidemic).

\section{Results}

The age-standardized incidence of KS continues to increase in KwaZulu-Natal. Between 1983 and 2006, agestandardized incidence rates in men increased from 1.04 to 19.7 cases per 100,000 , while in women they increased 50-fold, from 0.21 to 11.51 cases per 100,000. Overall, incidence has increased from 0.52 to 14.76 cases per

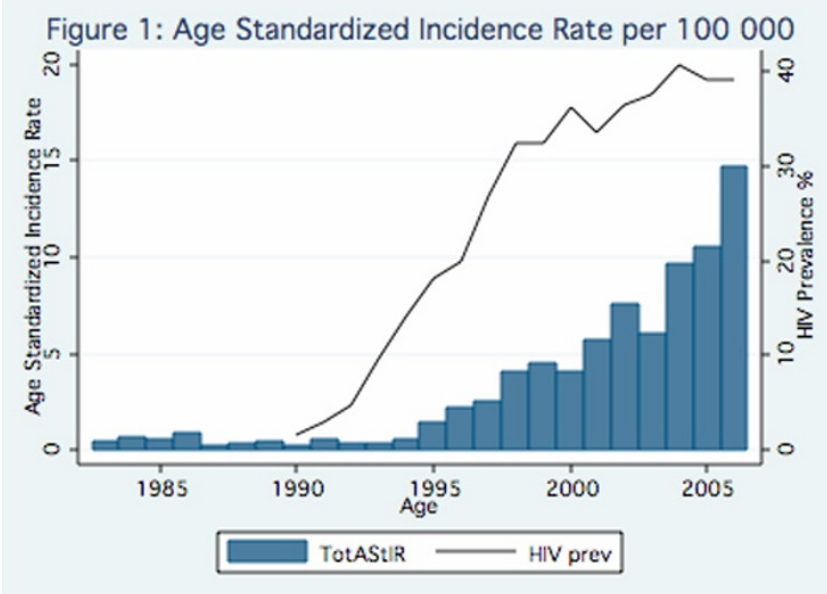

Figure I

Age standardized incidence rate per 100000. 
Figure 2: Age Specific Incidence Rate per 100000

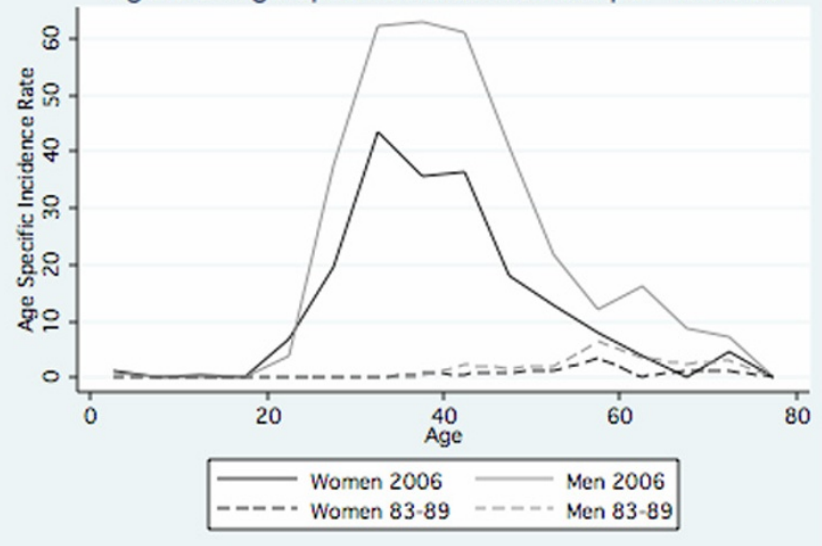

Figure 2

Age specific incidence rate per 100000.

100,000 (Figure 1). This pattern of increase mirrors that of the HIV antenatal clinic seroprevalence for KwazuluNatal, which increased steadily from 1.6 percent in 1989 to 39 percent in 2006. In 2006, peak age-specific incidence in men is 63.1 cases per 100,000 and in women is 43.5 cases per 100,000 (Figure 2), with peaks shifting to the fourth and fifth decades of life, compared to a peak incidence between ages 55-60 in the pre-HIV era (1983$1989)$. During the last decade, the mean male:female ratio was 2.3.

\section{Conclusion}

Our estimates of KS incidence are based only on those who are referred to public sector oncologists, and exclude both early and late stage KS that would be treated by primary care providers or hospice, as well as those treated in the private sector. We therefore greatly underestimate the true incidence AIDS-associated KS in the province, and absolute rates cannot be compared directly to cancer-registry data from other African countries. Nonetheless, we demonstrate that the incidence of AIDS-associated KS continues to increase through 2006, and is a growing public health problem in KwaZulu-Natal, South Africa.
Publish with Bio Med Central and every scientist can read your work free of charge

"BioMed Central will be the most significant development for disseminating the results of biomedical research in our lifetime. " Sir Paul Nurse, Cancer Research UK

Your research papers will be:

- available free of charge to the entire biomedical community

- peer reviewed and published immediately upon acceptance

- cited in PubMed and archived on PubMed Central

- yours - you keep the copyright

Submit your manuscript here:

http://www.biomedcentral.com/info/publishing_adv.asp 